\title{
Selfie for Attention: Practice of Hijab Selfie on Instagram
}

\section{Juliana Kurniawati ${ }^{1}$, Heddy Shri Ahimsa-Putra ${ }^{2}$, Budi Irawanto ${ }^{3}$, and Ratna Noviani ${ }^{4}$}

1Doctoral Student of Media and Cultural Studies Universitas Gajah Mada, Yogyakarta, Indonesia

${ }^{2}$ Lecturer at Faculty of Cultural Science Universitas Gajah Mada, Yogyakarta, Indonesia

${ }^{3}$ Lecturer at Faculty of Social and Political Sciences Universitas Gajah Mada, Yogyakarta, Indonesia

${ }^{4}$ Lecturer at Media and Cultural Studies Universitas Gajah Mada, Yogyakarta, Indonesia

\section{Abstract}

This paper studies digital self-portraiture (the 'Selfie'), a social phenomenon and part of modern life. The Selfiecity research project (2014) demonstrates that selfies are mostly done by women. However, there is little research related to the so-called 'hijab selfie'. Hijabed women deal with the tension between religious norms and their desire to be recognized. This paper considers the practice of hijab selfies using Foucault's concept,

Corresponding Author:

Juliana Kurniawati

juliana.kurniawati@mail.ugm

ac.id

Published: 29 July 2020

Publishing services provided by

Knowledge E

(c) Juliana Kurniawati et al. This article is distributed under the terms of the

Attribution License, which

permits unrestricted use and redistribution provided that the original author and source are credited.

Selection and Peer-review under the responsibility of the WCGS Conference Committee.

\section{G OPEN ACCESS} technologies of the self. This study also applies Theo van Leeuwen's social semiotics. This study is based on the compilation account @jilbab_chantik, an active account with more than 39,000 followers. Instagram is considered a space to celebrate the freedom of self-representation. Attention is indicated by the number of likes, comments, and increasing follower numbers. This compilation account @jilbab_chantik facilitates the desire of hijab women to add followers attaining their desire for recognition.

Keywords: Hijab Selfie, Instagram, Practice, Desire, Attention

\section{Introduction}

Selfie's term first appeared in the Australia online forum event in 2002 [1]. Selfie as a photo uploaded and shared appeared on the Flickr website in early 2004, when the smartphone began to be known by the public. Selfie, became viral in 2010 when front facing camera technology was used on the iPhone 4 [2]. Selfie became more famous after entering into one of the words in The Oxford English Dictionary in 2013. The word "selfie" has been named the word of the year [3]. Selfie is defined as the activity of taking pictures of yourself using a smartphone or webcam then uploading and sharing the photo on social media [1]. Another definition of selfie is a self portrait made in a reflective object or from arm's length [4]. As technology develops, selfies can be done using technologies such as selfie sticks, selfie air drones, timers on smartphones and gesture motion sensor technology on Samsung smartphones or SNAPI applications. 
Selfies are activities that smartphone users tend to like along with the popularity of visual-based social media like Facebook and Instagram. Selfiecity research project (2014) informs that selfies are mostly done by women than men (Retrieved from http://selfiecity.net/). The rise of selfie practices in various communities in the world has given rise to the idea of a national selfie day. In America, the National Selfie Day was first celebrated on June 21, 2014. It was started by DJ Rick McNeely from Fishbowl Radio Network, in Arlington TX. On this day a selfie photo contest was held as a way to get people to enjoy themselves and do it in a creative way (Retrieved from http://www.holidayscalendar.com/event/national-selfie-day/). In addition there is also a world social media day which is celebrated every 30 June was founded in 2010 by Mashable (Retrieved from https://nationaldaycalendar.com/social-media-day-june-30/). While social media day in Indonesia is celebrated every June 10th since 2015. It was founded by Handi Irawan D., CEO and Founder of Frontier Group, a company engaged in the field of Marketing and Digital Technology (Retrieved from https://techno.okezone. com/read/2017/06/10/207/1712637/10-june-happy-day-social-media)).

Whereas regarding a piece of cloth called hijab, in Indonesia the use of hijab and all its attributes is not prohibited by the government. Although it requires a long process, because at the beginning of the early era of the New Order the use of hijab was banned by the government. Hijab used by Muslim women in the New Order era was considered as an attitude of resistance to the prohibition of veiling. But as time and technology develop, the commodification and commercialization of religious symbols occurs [5]. We can observe in everyday life, the hijab becomes one of the trends in clothing that reflects a lifestyle that is no longer just to cover the head and hair as a religious rules. The used of the hijab is a reflection of identity, resistance, fashion and negotiation as part of a cosmopolitan cultural representation.

Constructed hijab women carry a number of religious values and norms that want to be obeyed which are sometimes contrary to the desire of women to self-actualization or to represent themselves in virtual public spaces through selfies. One of the norms in Islam originating from the Qur'an in the 24th verse of An Nur verses 30 and 31 explains that a man and woman should hold their gaze, a woman should cover her nakedness wearing a hijab over the chest, and prohibition to show the body in front of the opposite sex. However, the presence of communication technology has brought a shift towards the continuing construction of norms and values that have been built and are believed to be true by the public. As quoted from Karen Waltrop (2015) in Kavackci and Kraeplin "new technologies are often used to both follow and challenge social norm". Clearly defined cultural norms regarding what constitutes a public versus private space -and 
behavior appropriate for each- provide the framework for behavior, but social media offer opportunities to circumvent that framework" [6].

Selfie by women wearing hijab has caused various interpretations and controversies in society. In the range of 2014, cyberspace was stirred up by Ustad Felix Siaw's post on the @felixsiaw Twitter account that discussed selfies. The contents of the twitt include "selfies that mostly lead to TAKABBUR, RIYA, at least UJUB (Takabbur means to act as if one is better than others;Ujub means vanity; self-conceit (retrieved from http://www. zaynabacademy.org/ujub-kibr-takabbur/) Riya means show off (retrieved from https: //bincangsyariah.com/kalam/riya-adalah-syirik-kecil-dalam-islam-apa-maksudnya/)) for girls and boys, it's better to avoid the name selfie photos, there is no benefit to many harms, all three turn off the heart, burn off charity, and make it wither even before it bloom ". This twitt became a trending topic, which was covered by several local and international media.

Felix Siauw criticized hijab women who took selfies because they were concerned with the phenomenon of viral selfies that were increasingly favored by hijab women. Through his personal website Felix Siauw explains about the phenomenon of selfies that hit Muslim women as a concern for the waning of shame. Felix Siaw cites the results of research by Gwendolyn Seidman, associate professor at Albright College, which shows that selfie is closely related to narcissism and self-objectification (the tendency of self-amazement). Frequent uploading of selfies is also associated with high levels of narcissism and psychopathic tendencies.

Women's desire to present themselves cannot be easily channeled given the limitations of religion and a set of social rules. As Linda Arthur's writings "Hijab involves the control of the bodily space of women especially in those instances involving the spatial relationship between men and women" [6]. In addition to expressing Felix Siaw's concern about selfies, there is an anti-selfie movement for Muslims on Instagram as can be found in the accounts of @ukhtiakhiantiselfie, @shalihatanpaselfie, and @kartun.muslimah. On the other hand, in the Instagram space, a number of compilation accounts appear that show selfie photos of women wearing hijab in various poses.

Based on observations on Instagram it was found that there were hijab compilation accounts featuring selfie hijab. There are accounts likes @jilbab_chantik, @jilbab_sweet, @id_mawarmerah, @selfie.hijab_, @selfie_mukena, @cantikituberhijab, @hijabcantikz, @hijabers.cantique, @jilbab_dewasa, @pesonahijaberindo and @hijaberkece. The accounts above are compilation accounts that promote hijabed women photos of several followers sending photos via direct message to the admin. The photos in the account show various selfie styles of hijabed women. This research analyzes 
compilation accounts @jilbab_chantik which features the hijabed women selfie using concept technologies of the self by Michel Foucault and social semiotics by Theo van Leeuwen.

\section{Literature Review}

Research on selfie practice has been conducted by many scholar and researcher. Theresa M. Senft and Nancy K. Baym wrote paper about this with the titled is What Does the Selfie Say, Investigating a Global Phenomenon published in the International Journal of Communication 9 (2015). This research describes the journey of selfie as a global phenomenon [7]. \#selfie: digital self-portraits as commodity form and consumption practice, this article examines about selfie uses as commodity by Mehita Iqani and Jonathan E. Schroeder (2015). Another study related to selfie entitled The Selfie as a Global Discourse by Aslaug Veum and Linda Undrum. This research present a critical multimodal discourse analysis of how people make meaning through the semiotic practice of shooting digital selfie [3]. The other title is On friendship, boobs and the logic of the catalog: Online self-portraits as a means of capital exchange this article discusses the self-portrait which is interpreted as a process of emancipation as a means of increasing self-value as a currency in cultural exchange and social capital that is analyzed using the theory of cultural production by Bourdieu [9]. Article Religious Beings in Fashionable Bodies: the Online Identity Construction of Hijabi Social Media Personalities, discusses about constructed identity online three hijabista [6]. This paper is different from the articles above, the focus of this paper is on the practices of hijabed selfie which publish on Instagram's compilation accounts @jilbab_chantik.

\section{Methodology}

Type of research is qualitative using technologies of the self concept and social semiotics theory approach to reveal the textual aspects representation of the hijab selfie. Research subjects is account @jilbab_chantik (39 thousand followers), 512 photo's posting (by the date of Sept 18, 2019) with captions and hashtag accompanies the photos. Technique of data collection is observation of hijab selfie and caption posted by @jilbab_chantik. This paper choosen compilation account @jilbab_chantik as corpus because it is an account that has an active admin (Admin is someone who manages accounts on social media platforms). As for the corpus of the study, several photos will be selected with the criteria of having the most likes and the least likes. As a form of 
self-representation to the photos which post in 2018, January until 2019, August. Hijab selfie shows the complex interaction between identity politics and women's aesthetic self. Various poses, facial expressions, backgrounds, various accessories are displayed on the compilation account. The emergence of a compilation account on Instagram that contains hijab selfie photos is interesting to be an in-depth study of how hijab women represent themselves as subjects in the Instagram space. Hijab selfie will be analyzed using social semiotics with multimodal text analysis tools such as the table below:

\begin{tabular}{|l|l|l|}
\hline \multirow{2}{*}{ Function of meaning } & \multicolumn{2}{|c|}{ Semiotic resources } \\
\cline { 2 - 3 } Representational & \multicolumn{1}{|c|}{ Visual resources } & Linguistic resources \\
\hline meaning & $\begin{array}{l}\text { Contextualized/decontextualized } \\
\text { Degree of visual modality } \\
\text { Narrative/conceptual }\end{array}$ & Lexis \\
\hline \multirow{5}{*}{ Interactional meaning } & $\begin{array}{l}\text { Social distance } \\
\text { > Personal (close up) } \\
\text { > Social (medium shot) } \\
\text { > Impersonal (long shot) } \\
\text { Image act } \\
>\text { Offer (absence of gaze at } \\
\text { viewer) } \\
>\text { Demand (direct gaze) } \\
\text { Attitude } \\
>\text { Low-angle shot } \\
>\text { Eye-level shot } \\
>\text { High-angle shot }\end{array}$ & Style \\
\hline Compositional meaning & $\begin{array}{l}\text { Relation between visual and linguistic resources } \\
\text { Communicative act } \\
\text { (speech act) }\end{array}$ & \\
\hline
\end{tabular}

Figure 1: Multimodal text analysis of selfies and captions publish on Instagram [3]

\section{Results and Disscusion}

It's hard to imagine a world without Instagram [9]. Some people who live in the millennium era and have difficulty using social media in their daily lives will find it difficult to start by posting photos or videos on their Instagram accounts or uploading them on InstaStory. Instagram (IG) is one of the social media that is used to communicate on the internet network which was launched in 2010. One of Instagram's uploads is selfie, included Hijab selfie.

Instagram has two types of accounts, namely a personal account containing photos of themselves, family and friends of the account owner and a compilation account that contains a combination of photos of several people who may not know one another. 
In a personal account, someone acting on his own behalf, he has the freedom to upload photos and videos that he can choose himself. Although it does not rule out the possibility of a famous artist such as Zaskia Sungkar or Dian Pelangi hiring someone else as an admin to take care of her social media accounts, the power remains in the hands of the account owner. Whereas in this compilation account, the admin has the duty to operate the account, the admin acts as the person in charge to determine who can upload his photos to the compilation account. Admin has account rules that are usually written on the profile page. As an example the admin writes: bad words = block, or do promotions like this: follow our partner.

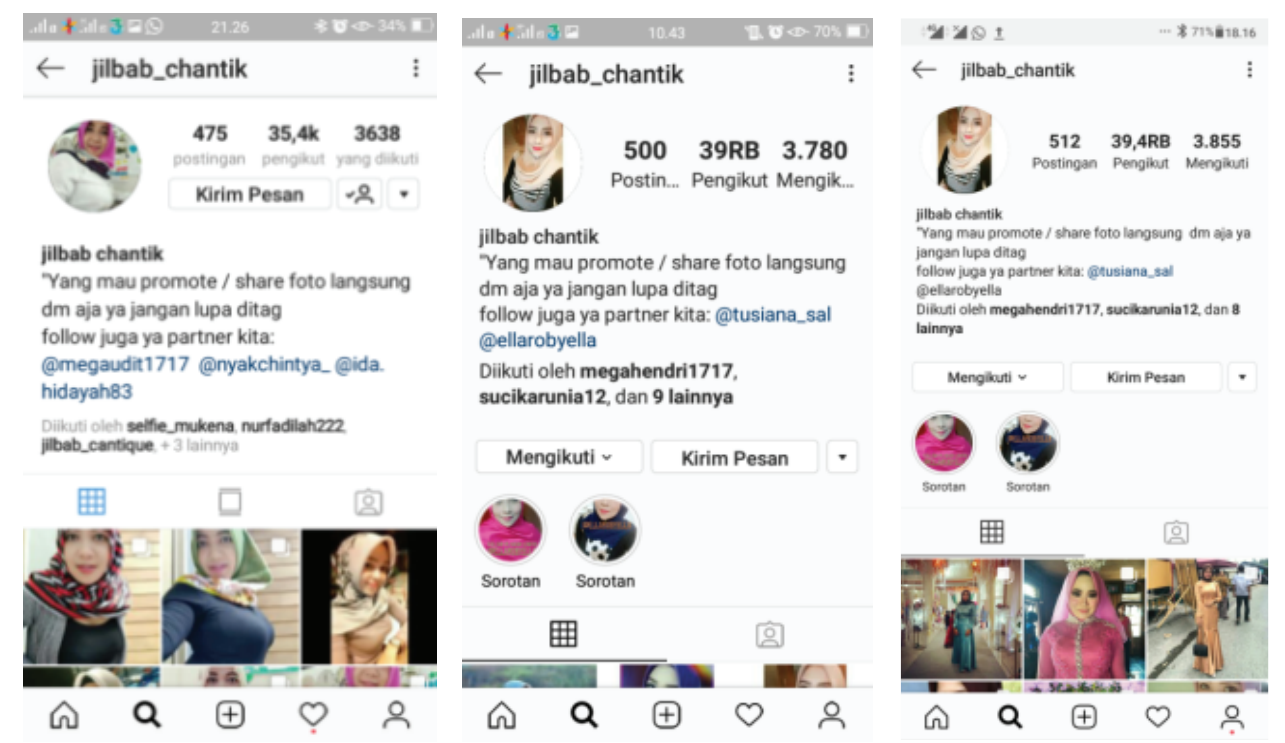

Figure 2: Home of compilation accounts @jilbab_chantik

Fig. 2 is home view of @jilbab_chantik compilation account, it is the result of a screen shoot conducted on 13 August 2018, 6 July 2019, and 18 September 2019 (from left to right). There is an increase in terms of posting, followers and following. The number of posts moves from the numbers 475, 500 then 512. The number of followers from $35.4 \mathrm{~K}$, the next 39RB 39.4RB. $\mathrm{K}$ is an abbreviation of Kilo which means thousand. Instagram uses $\mathrm{K}$ to indicate the number of followers and follows, then changes to RB (Thousand). In the description section there is a change to the name called "follow juga ya partner kita". On the display side of Instagram also changes the word "yang diikuti" to "mengikuti" the position of the word "kirim pesan" at the top to be in the middle, the symbol or icon follows to the words "mengikuti". The dominant white background in Fig 2(a) appears grayish in Fig 2(b\&c). In 2(b\&c) two photos appear in the frame of the spotlight. Highlights are the results of posts in Instastory that are stored in the account. Fig 2(d) is caption and hashtag accompanies the hijab selfie. This changed proved that digital media is fluid. 


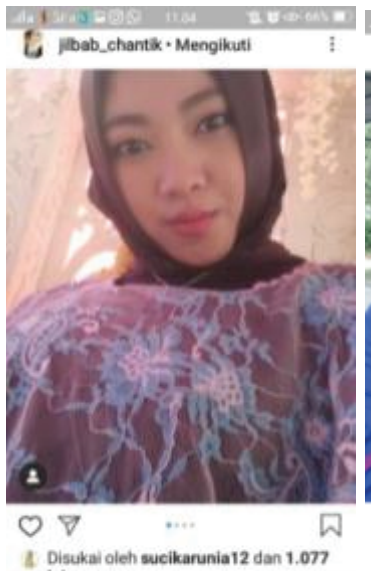

@ $\quad \oplus \quad \circ \quad 8$

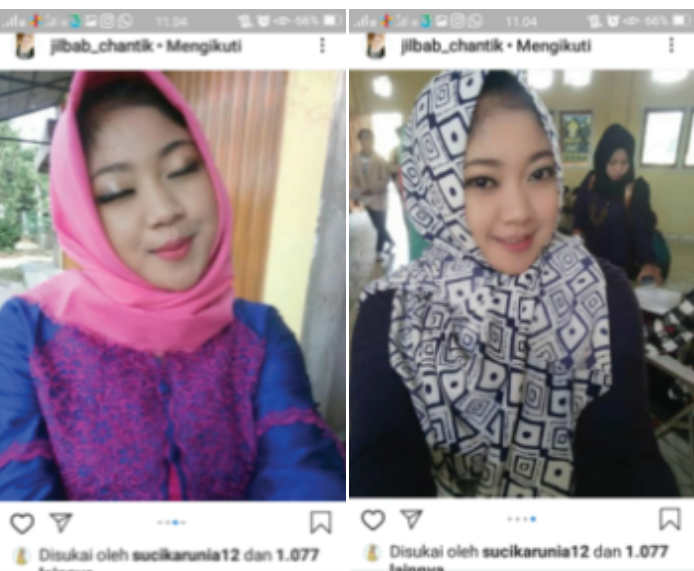

ऽ $\quad \oplus \circ 8$

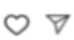

Disukai oleh sucikas jibab_chantik Follow kakak kece

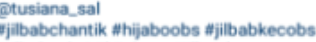
Nijlibabseksi Nhijabers tjilboobs Fijibabfashion Ijilibabfashionstyle

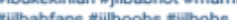

Figure 3: Screen shoot from @jilbab_chantik on July 6, 2019

Three screen shot images (fig.2) above are one person selfie hijab who send several photos to the admin via Direct Message. Hijab selfie posted on November 7, 2018 is the photos which has the most number of likes compared to other photos. This photos got 1,078 likes. The accompanying caption wrote the follow sister kece by mentioning the account @tusiana_sal as the photo owner's identity. The accompanying hashtag is \#jilbabchantik \#hijaboobs \#jilbabkecobs \#jilbabseksi \#hijabers \#jilboobs \#jilbabfashion \#jilbabfashionstyle \#ibukekinian \#jilbabhot \#mamahmuda \#jilbabfans \#jilbobs (fig 2d). All of three photos are wearing hijab that varies in color, with shooting angles and expressions that also vary. Instagram as a digital media platform that records posts can change at any time, not fixed. These changes are found in Fig 3(a) which was the result of screen shoot on September 18, 2019. This post received an additional 9 likes became 1,087 , but possibility change.

Fig $3(b)$ is a hijab selfie posted on January 5, 2018, getting 99 likes is the least number of likes among others. The caption on this upload is "follow ya cantik@ putriamelia_97". The accompanying hashtag \#jilbabchantik \#jilbabootd \#jilbabfashion \#hijabootd\#jilboobs \#hijaboobs \#jilbobs.

Hijab selfie in compilation account @jilbab_chantik will be analyzed with fig. 1 to reveal representation, interaction, and compositional meaning. Visual dan linguistic resources as a text intertwines with the social context in which the text is produced and used, there are integration between text and context.

In representational meaning in the visual resources section there are three points that will be analyzed namely contextualized / decontextualized, degree of visual capital, narrative / conceptual. The first point is the selfie photo is contextualized or decontextualized. I will do the analysis by looking at the background depicted in the photo that 

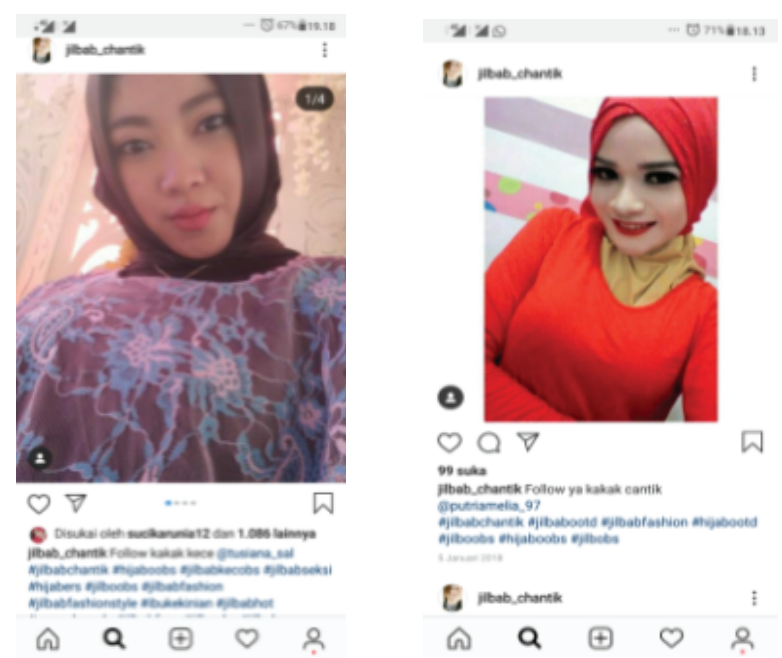

Figure 4: Screen shoot from @ jilbab_chantik on September 18, 2019

does not appear or does not fully appear in the image. As Machin said that "A reduction in background details can be achieved in several ways, for instance by shooting the image in a studio or by using digital tools such as cropping or blurring" [3].Corpus data contains various of less contextualized and decontextualized representations. On @tusiana_sal's hijab selfie, you can find that only one photo is in decontextualized, the background is absent even not fully absent. While the other photos is in contextualized, we can still see the background behind it as in fig 2(c) it appears that two people are behind the social actor or also called represented participant. In the @putriamelia_97's photo include in decontextualized, the background is absent even we still can saw a little what is behind.

The second point is the degree of visual modality, which is about the degrees of editing. The general principle is that the image of something resembles how we see it with our own eyes, the higher the degree of naturalistic equity [3]. All photos uploaded through the editing process, at least editing on lighting and cropping. Beautify features in the camera application are also activated to support the process of making photos as the representation desired by social actors.

In the third point is about the narrative or conceptual elements contained in the photo. The action of selfie photos on the @tusiana_sal and @putriamelia_97 are included in the conceptual category because the selfies they upload are performing act because the two of them depicted not done activity or in passive position. The representation is static because representing oneself on Instagram.

In representational meaning related to linguistic resources is analyzing the uploaded caption and hashtag to give information or strengthen the story in the photo. The two caption in these photos mentions the owner of the photos, had the same pattern like 
"follow kakak kece....... or follow ya kakak cantik......". Caption and hashtag produced describe the represented person and for the viewers who understand the lexis presented.

In interactional meaning in visual resources, there are three points of analysis, namely social distance (close up/personal, medium shot/social, long shot/impersonal), image act (offer, demand), attitude (low-angle shot, eye-level shot, high-angle shot) These two social actor builds personal interaction, namely the position of taking a close-up photo. All photos were taken using the arm of the social actor, not a single selfie was taken using the help of selfie stick. Hijab selfie here in the corpus of this research are in the position of demand (direct gaze) of the viewer except fig 2(b). Fig 2(b) represent absence of gaze at viewer (offer) with close her eyes. Even close her eyes but her body straight to the camera. They build interactions to make it appear that they will be in close proximity and reached by the viewer. In attitude, they are pratices two attitude in low-angle shot shooting techniques as contained in fig. 2(a) and eye-level shot at fig. 2(b\&c); 3(b). Low angle's mean indicating the power of the selfie maker power while at eye level shoot, there is a symbolic equality and symmetrical relation. Low angle makes it look imposing and awesome generally give an impression of superiority exaltation and triumph [10].

In the linguistic resources section interactional meaning there is a point style and communicative act, we can observe the use of language in the caption and hashtag that accompanies the selfie. The caption in this compilation account is advertising style and use various communicative act in hashtag. Captions and hashtags are displayed in Indonesian with the aim to be consumed by viewers or followers who understand Indonesian. Captions and hashtags that are present here use promotional words, requests, demands, offering or demanding something. Hashtag uses slang language that invites viewers to see the photo owner's account and become his follower.

The compositional meaning section will analyze the relation between visual and linguistic resources. There are three principle: information value, salience, framing. There is a relationship between visual and linguistic resources where both complement each other's narratives that they are built. Social actor fig. 2(a,b,c) placed herself in the middle (ideal position) of image or in the centered composition. In fig 3(b) social actors tend to be in the right position. Points highlighted in fig 2(a) are large breasts, whether they are genuine or not and eye contact. In fig $2(b \& c)$ highlighting face makeup and hijab color. While fig 3(b) accentuates the breasts along with the colors of clothes and hijab. Salience is judge on the basis of visual clues, the degree to which an element draws attention [10]. Framing is built from verbal modes that are related to visual modes. 
The connection between verbal and visual modes determines the framing formed. Fig 2 ( $a, b, c)$ and Fig 3 (b) form the same framing which is a beautiful and sexy selfie hijab. Hijab selfie uploaded on Instagram as a means of showing self representation and interaction in cyberspace in order to get attention. Representation is a process in which the makers of signs seek to make representation of some object or entity, whether physical or semiotic and in which their interest in the object, at the point of making the representation, is complex one, arising out of the cultural, social and psychological history of the sign maker and focused by spesific context in which the sign maker produces the sign [10]. Instagram's presence has changed the way many Indonesian people represent themselves in image sometimes without knowing pay attention on public or private spheres to fulfill their pleasure and desire.

As Foucault'concept about Technologies of the self is a certain number of operations on their own bodies, on their own soils, on their own thought, on their conduct, and this is a menner so as to transform themselves, modifi themselves, and to attain a certain state of perfection, happines, of purity, of supernatural power [11]. Within self there are techniques in which a person can use them to achieve happiness in life even though sometimes it causes controversy but they can negotiated it. This inner technique is used by hijab women to fulfill her desire by practicing the hijab selfie. When a woman fulfills her desire for self-representation, she has become a subject that has an agenda for herself. In this compilation account there are two side of desires and happines fulfill. That are the admin and women in the account's desire. Selfie is a practice of technologies of the self in virtual space, where the self is free to construct identity through photos. Regarding identity in cultural studies is about how identity is understood as anti-essentialist.

The practice of selfie photos actually activates itself more likely in subjects position whom free to determine the angle and which photos will be uploaded to replace the photographer's role. Although there are subject positions intertwined during selfie practice as is Ana Peraica mentions selfie as a social paradox. Related to the relationship between subjects, objects, and viewers in selfie practice. In the practice of selfie space between objects, subjects and viewers blend in, constructing hybrid space. There was also an intermingling between public space and private space in photography due to obscurity that occurred between objects, subjects and viewers. Peraica mentioned that Selfies are two opposing processes "subjectification of space an objectification of self, Transfers from self to the picture, from subject to object, I will name objectification, while rarer transfer from object to the subject, subjectification" [12]. But when the selfie 
photos has been sent to the compilation account admin, that's when the self becomes an object for itself.

\section{Conclusion}

Selfie as part of a digital lifestyle has attracted some people to practice it. Hijab women practice selfies as a way to fulfill the desire to get attention on Instagram which is manifested through likes and increasing numbers of followers. The self-narrative built in the private sphere is now awakened in the public sphere through digital visualization. A variety of Instagram protocols that facilitate selfies make users willing to exploit themselves. Compilation account exists to facilitate and mediate the desire of some hijabed women to add followers to their personal accounts. Hijabed women seem to have freedom for self-representation but in fact they must negotiated their desire. The hijab woman negotiates the prohibition of presenting herself by continuing to wear the hijab, dressed in a tight and practicing the aesthetics of herself make up the face and fashionable. But consciously or not, they made themselves as objects on Instagram. This compilation account also controls followers who want their photos to be promoted or published. Selfie practices that are truly a reflection of self-determination, determining poses, angles, expressions, hijab styles, accessories, etc. have changed because they must obey to admin rules in this compilation account. @ jilbab_chantik carries a sexy woman's hijabed selfie discourse "if you want to get attention, you must have big boobs". Compilation accounts use Instagram to influence their followers in setting beautiful standards according to admin criteria. Admins tend to display hijab selfies on their accounts in the terms "this is how I want to be....", not "this is me". Research on hijab selfie has not been done much. Opportunities to explore the research theme are open. More in-depth research can be done, for example, research about the hijab selfie on selebgram account or on microcelebrity accounts. To see the self narrative which built into the account using virtual ethnographic methods.

\section{Acknowledgments}

The authors would like to thanks to Postgraduate School of Universitas Gajah Mada and my promotor team: Prof. Heddy Shri Ahimsa-Putra, Dr. Budi Irawanto, and Dr. Ratna Noviani for their valuable support. 


\section{References}

[1] Murray, D. C. (2015). Notes to Self: The Visual Culture of Selfies in the Age of Social Media. Consumption Markets \& Culture, vol. 18, issue 6, pp. 490-516.

[2] The Guardian. (2013, July). How Selfie Became a Global Phenomenon. Retrieved from http://www.theguardian.com/technology/2013/jul/13/how-selfiesbecame-a-global-phenomenon

[3] Veum, A. and Undrum, L. (2017). The Selfie as a Global Discourse. Discourse and Society, vol. 29, issue 1, pp. 86-103.

[4] Tiidenberg, K. and Cruz, E.G. (2015). Selfies, Image and the Re-Making of the Body. Body \& Society, vol. 21, issue 4, pp. 77-102.

[5] Heryanto, A. (2015). Identitas dan Kenikmatan Politik Budaya Layar Indonesia. Jakarta: Gramedia.

[6] Kavakci, E. and Kraeplin, C.R. (2017). Religious Beings in Fashionable Bodies: the Online Identity Construction of Hijabi Social Media Personalities. Media Culture and Society, vol. 39 , issue 6 , pp. 850-868.

[7] Senft, T.M. and Baym, N. K. (2015) What Does the Selfie Say? Investigating a Global Phenomenom. International Journal of Communication, vol. 9, pp. 1588-1606.

[8] Schwarz, O. (2010). On Friendship, Boobs, and the Logic of Catalogue: Online SelfPortraits as a Means for the Exchange of Capital. Convergence: The International Journal of Research into New Medai Technologies, vol. 16, issue 2, pp. 163-183.

[9] Time. (2016, July). A Brief History of Instagram's Fateful First Day. Retrieved from https://time.com/4408374/instagram-anniversary/.

[10] Kress, G. and van Leeuwen, T. (2006). Reading Images: The Grammar of Visual Design ( $2^{\text {nd }}$ ed.). London: Routledge.

[11] Foucault, M. (1998). Technologies of the Self: A Seminar with Michael Foucault. London: Tavistock.

[12] Peraica, A. (2017). Culture of the Selfie: Self-Representation in Contemporary Visual Culture. Amsterdam: Institute of Network Cultures. 